\title{
Electrochemical Degradation of Textile Effluent Using Novel Ozone Generating Sn-Sb-Ni Anodes
}

\author{
[ Taner YONAR* and Özge SIVRİĞLU ]
}

\begin{abstract}
The application of $\mathrm{Sn}-\mathrm{Sb}$-Ni electrodes for the treatment of waste streams is promising for ozone production by electrolysis of water because of their stability and over potential for the oxygen evolution reaction. These series of anodes have high electrochemical ozone generation potential at ambient conditions (apprioximately 40\% current efficiency). But the usinng and testing of these novel anodes for real wastewater are too limited in literature. Titanium mesh substrate coated with Sn$\mathrm{Sb}$-Ni alloy was used as anode immersed in wastewater at room temperature with platinised titanium cathode. Five operational parameter ssuch as: initial dye concentration, $\mathrm{pH}, \mathrm{COD}$, applied voltage/current and the contact time were evaluated for the ozonation process. Experimental findings revealed that after 30 min the degradation efficiency of dye and COD could reach upto $99 \%$ and $98 \%$ respectively at $\mathrm{pH} 3$ and temperature of $25^{\circ} \mathrm{C}$ as the optimum conditions.
\end{abstract}

Keywords- Elelctrochemical ozone gerenartion, textile wastewater, COD, colour

\section{Introduction}

Textile dyehous effluents usualy generates primarily high amount of coloured and organic waste contents. These pollutants creates aesthetic and toxic problems on water bodies. Strict discharge regulations and public demand of color-free effluent dictate a colour removal process applications for industries [1]. Traditional processes including physico-chemical and bilogical stages can not treat colour content of textile industry [2]. From these reason different treatment alternatives are getting attention for treating coloured and toxic content of textile wastewater in last two decades.

Electrochemical treatment of synthetic dyestuff was studied in literature widely and 80-95\% COD and colour removal efficiencies reported [3,4,5]. During these studies diffrent types of anodes were used. In last years, $\mathrm{Sn}-\mathrm{Sb}$ $\mathrm{Ni} / \mathrm{Ti}$ anodes shows superior performance on electrochemical ozone generation studies [6]. But the testing of these anodes on synthetic or real wastewater samples are too limited in literature. $[7,8,9,10,11,12]$.

Taner YONAR/Assoc.Prof. (Corresponding Author)

Uludag University

Turkey

Ozge SIVRIOGLU/Res.Asst.

Uludag University

Turkey
Current technology in ozone production utilizes several techniques [13] but in situ ozone can be generated by following technologies: (i) Corona discharge (dielectric barrier discharge); (ii) UV irradiation (photochemistry) and (iii) Electrochemical ozone production (electrolysis of aqueous solutions) $[9,14]$

Corona process, which is the traditional way to produce ozone, utilizes electrical discharges. In this process ozone is generated by passing dry oxygen or air through a high energy electric field, which oxygen is converted into ozone, generated an AC high voltage applied across plate and ground electrodes covered by dielectric $[13,14,15]$. For the efficiency of ozone generation $\left(\mathrm{O}_{2}+\mathrm{O} \rightarrow \mathrm{O}_{3}\right)$ in Corona discharge following factors are important; (i) oxygen source, (ii) gas temperature and (iii) presence of impurities in the gaseous phase [10]. The second type of ozone generation is UV irradiation at $185 \mathrm{~nm}$ but ozone concentration is lower and enery consumption is higher than corona discharge. Also periodic replacement of UV lamps makes additional expenses [12]. And the third type ozone generation is electrochemical process where water is used as electrolyte and at anode and cathode water dissociates into hydrogen and oxygen ( See Eqs. 1-3) [16]. Ozone is generated at the anode surface and it competes with $\mathrm{O}_{2}$ evolution cause it always occurs during electrochemical ozone generation since it is thermodinamically favorable $[17,18]$ (See Eq. 4):

\section{Anode Reaction}

$$
\begin{array}{lll}
\mathrm{O}_{3}+6 \mathrm{H}^{+}+6 \mathrm{e}^{-} \Leftrightarrow & 3 \mathrm{H}_{2} \mathrm{O} & \mathrm{E}_{0}: 1,51 \mathrm{~V} \\
\mathrm{O}_{3}+2 \mathrm{H}^{+}+2 \mathrm{e}^{-} \Leftrightarrow & \mathrm{H}_{2} \mathrm{O}+\mathrm{O}_{2} & \mathrm{E}_{0}: 2,07 \mathrm{~V}
\end{array}
$$

Cathode Reaction

$2 \mathrm{H}^{+}+2 \mathrm{e}^{-} \longrightarrow \mathrm{H}_{2}$

Oxygen Evolution

$$
\mathrm{O}_{2}+4 \mathrm{H}^{+}+4 \mathrm{e}^{-} \Leftrightarrow \quad 2 \mathrm{H}_{2} \mathrm{O} \quad \mathrm{E}_{0}: 1,23 \mathrm{~V}(4)
$$

Electrode materials and the reactor design affects the efficiency of electrochemical ozone generation also current efficiency can be influenced by electrode morphology, cell configurations, current density, electrolyte, anodic potential, and temperature [12]. Among these factors anodic material is one of the most important parameter cause it must be carefully chosen to achieve appreciable ozone evolution with considerable efficiency. It must have a high over potential to prohibit the oxygen evolution and be stable to strong anodic polarization in the electrolyte. Several anode materials have been investigated, $\mathrm{Pt}, \mathrm{DSA}, \mathrm{Au}, \mathrm{Pd}, \mathrm{PbO}_{2}$, $\mathrm{SnO}_{2}$, boron doped diamond (BDD) and glassy carbon are some of them [13]. It can be clearly seen from the literature that $\mathrm{Pt}$ and $\mathrm{PbO}_{2}$ anodes have shown higher current efficiency $6.5-35 \%$ at low temperature and $13 \%$ at room temperature respectively. It's notable that $\mathrm{Sn}-\mathrm{Sb}-\mathrm{Ni} / \mathrm{Ti}$ anodes have shown the highest efficiency about $<36.5$ at room temperature [20]. On the other hand, durability of Sn$\mathrm{Sb}-\mathrm{Ni} / \mathrm{Ti}$ anodes are relatively higher and price are lower 
than other ozone generating anode configurations. But the testing of these anodes on real textile wastewater can not be detected by authors in accessed literature.

The aim of this study is to investigate the treatment efficiency of new anode configuration ( $\mathrm{Ti}$ mesh anode coated with $\mathrm{Co}-\mathrm{Sn}-\mathrm{SnCl}_{4}$ ) on real textile wastewater. Color and COD has been selected as target pollutant because of their importance for textile effluent.

\section{Experimental}

\section{A. Chemicals}

$\mathrm{SnCl}_{4} .5 \mathrm{H}_{2} \mathrm{O}$ (Alfa Aeser), $\mathrm{Sb}_{2} \mathrm{O}_{3}$ (Merck), $\mathrm{HCl}$ (Merck), $\mathrm{H}_{2} \mathrm{SO}_{4}$ (Merck), ethanol (Merck), oxalic acid (Merck) were used without further purification. All solutions were prepared by using Millipore Milli-Q $(18 \mathrm{M} \Omega \mathrm{cm})$ water. Wastewater samples were collected from the treatment plant of a fabric dyeing textile industy,Bursa, Turkey The textile wastewater samples were collected from an equalisation tank of a textile dyeing factory treatment plant. Environmental caharacterization of collected sample given in Table 1.

TABLE I. ENVIRONMENTAL CHARACTERIZATION OF RAW HANDPRINTED TEXTILE EFFLUENTS

\begin{tabular}{ccc} 
Parameter & Unit & Value \\
\hline COD & $\mathrm{mg} / \mathrm{l}$ & $2320 \pm 40$ \\
Suspended Solids & $\mathrm{mg} / \mathrm{l}$ & $120 \pm 20$ \\
$\mathrm{NH}_{4}-\mathrm{N}$ & $\mathrm{mg} / \mathrm{l}$ & $42 \pm 1.6$ \\
Free chlorine & $\mathrm{mg} / \mathrm{l}$ & $<0.1$ \\
Total chromium & $\mathrm{mg} / \mathrm{l}$ & $<0.1$ \\
Sulphur & $\mathrm{mg} / \mathrm{l}$ & $<0.1$ \\
Sulphide & $\mathrm{mg} / \mathrm{l}$ & $<0.2$ \\
Phenol & $\mathrm{mg} / \mathrm{l}$ & $<0.1$ \\
pH & - & 7.2 \\
Condcutivity & $\mathrm{mS} / \mathrm{cm}$ & 2,25 \\
Colour $^{\mathrm{a}}$ & $1 / \mathrm{cm}$ & 1.02 \\
\hline
\end{tabular}

a. Absorbance at $610 \mathrm{~nm}(\mathrm{SM} 2120 \mathrm{C})$

\section{Electrode preparation (Coating)}

Ti mesh substrates (Dexmet, USA) $(2.5 \times 2.5 \mathrm{~cm})$ were treated in $10 \%$ boiling oxalic acid for half an hour, sonicated with distilled water for 10 minutes 3 times by using ultrasonic bath and dried naturally in room temperature. The Ti-mesh electrodes were dip coated by pyrolysis solution consists of $\mathrm{Sn}-\mathrm{Sb}-\mathrm{Ni}$ in the molar ratio of 500:8:0,5. The electrode was doped into solution and it was dried in an oven at $105^{\circ} \mathrm{C}$ for $15 \mathrm{~min}$. In the final heating step electrodes were And then annealed in preheated furnace for $15 \mathrm{~min}$ at $520^{\circ} \mathrm{C}$. The coating cycle was repeated 15 times. In the final heating step electrodes were annealed for 75 minute. A 5.0 $\mathrm{cm} \times 5.0 \mathrm{~cm}$ platinized titanium electrode (NRK Electrochem) was used as cathode.

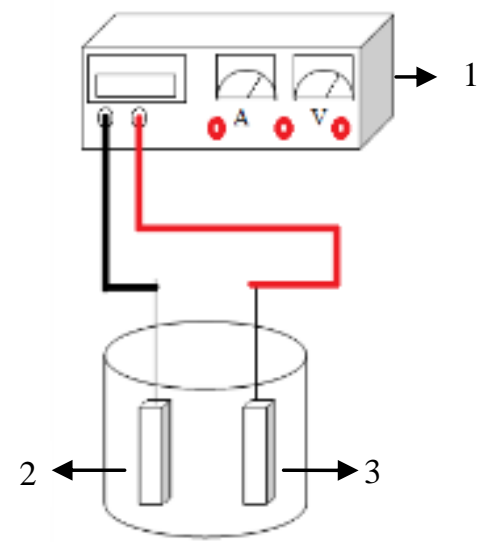

Figure 1. Experimental setup used in electrochemical ozone generation: (1) power supply (2)anode, ,(3) cathode

\section{Analyses}

Electrochemical ozone generation and ozonation of textile industry wastewater were carried out using the experimental set up presented in Fig 1.

All the experiments were performed in an undivided cell with volume $250 \mathrm{ml}$. pH was measured using a $\mathrm{pH}$ meter (Cyberscan 10). COD measurements were also carried out to investigate the mineralization according to closed reflux, titrimetric method. The electric current was provided by a programmable DC power supply (Extech Instruments382280).

The removal efficiencies of the parameters evaluated and was determines by using Eq. (5) as follows:

Removal $(\%)=\left(\left(\mathrm{C}_{0}-\mathrm{C}_{\mathrm{t}}\right) / \mathrm{C}_{0}\right) \times 100$

In this equation $\mathrm{C}_{0}$ and $\mathrm{C}_{\mathrm{t}}$ are concentrations of dye absorbtion and COD, at initial and any

reaction time respectively. The energy consumption per unit $C O D$ removed $\left(E_{C O D}\right)$ was calculated accoring to Eq. (6).

$$
E_{C O D}=\left(E_{\text {Cell }} I t\right) /(V \triangle C O D)
$$

where $E_{\text {cell }}$ is the energy consumption in $\mathrm{kWh} / \mathrm{gCOD}$; $E_{C e l l}$ is the average cell voltage in volt, I is the current in A and $\mathrm{t}$ is the electolysis time in hours, $\mathrm{V}$ is the solution volume in $\mathrm{L}$ and $\triangle C O D$ is the experimental COD decay in $\mathrm{mg} / \mathrm{L}$.

\section{Results and Discussion}

\section{A. Effect of Sodium Chloride concentration}

The effect of sodium chloride $(\mathrm{NaCl})$ concentration on removal of colour and COD from textile wastewater was tested in varied concentrations of $0.5 \mathrm{~g} \mathrm{~L}^{-1}-2 \mathrm{~g} \mathrm{~L}^{-1}$ (at constant current $50 \mathrm{~mA} / \mathrm{cm}^{2}$ and $\mathrm{pH}=7.2$ ). Salt content is playing a crucial role for electrochemical processes to increase the conductivity of treated wastewater [21,22]. Textile dyestuff solution includes high amount of salt (40$100 \mathrm{~g} / \mathrm{L}$ ) as a catalyst during the dyeing process [23]. Salt 
concentration is reduced with the addition of freshwater for washing and cleaning stages of fabrics. But, at the end of the dyeing and finishing processes, textile wastewater still includes high enough amount of salt content for electrochemical processes. Sn-Sb-Ni anodes has well known and high ozone generation capacity [6,24]. But high amount of salt generates another important oxidant chlorin gas and hypochloric acid [22]. On the other hand, salt addition generates additional operational cost and environmental pollution problem for most low conductivity including waste streams. From these reasons, textile wastewater is very fit for treating with electrochemical processes from the reason of high salt content.

As seen in the Fig.2 and Fig.3, increasing $\mathrm{NaCl}$ concentrations positively affect COD and colour removal efficiencies.

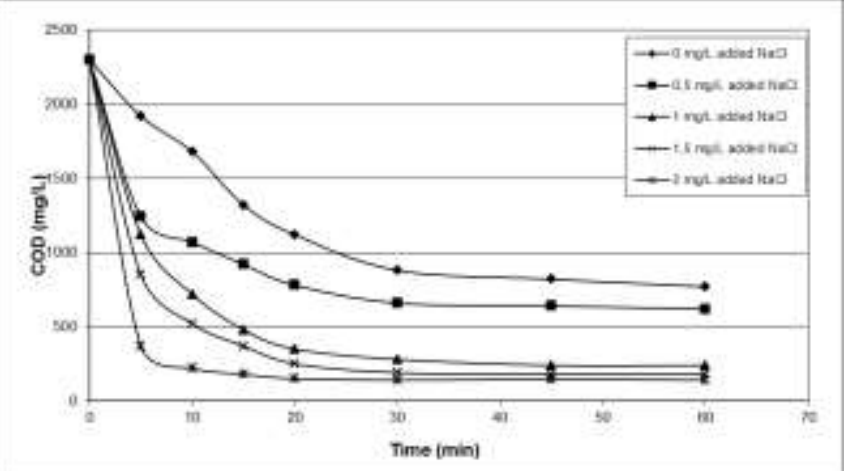

Fig.2 Effect of $\mathrm{NaCl}$ addition on COD removal $\left(\mathrm{I}=50 \mathrm{~mA} / \mathrm{cm}^{2}, \mathrm{pH}=7.2\right)$

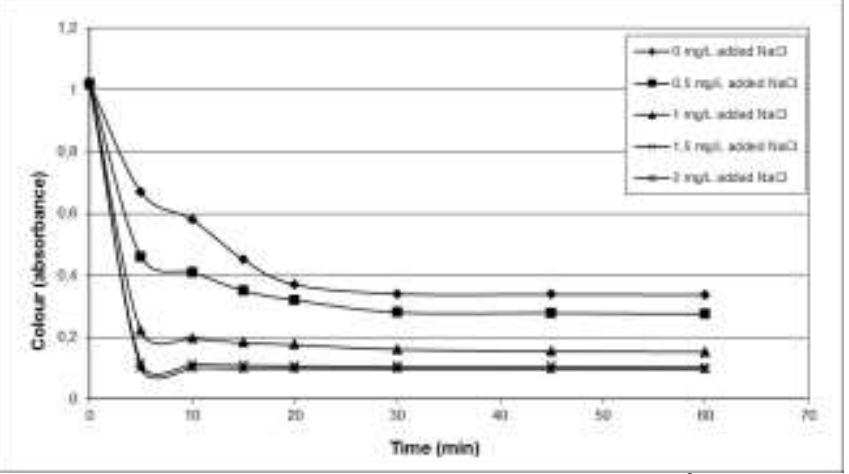

Fig.3 Effect of $\mathrm{NaCl}$ addition on colour removal $\left(\mathrm{I}=50 \mathrm{~mA} / \mathrm{cm}^{2}, \mathrm{pH}=7.2\right)$

At constant current $\mathrm{pH}$ vallues salt eddition shown important amount of COD colour removal. These results were determined witout any rpimary treatment or purification process/processes. Actually, no salt added samples has shown satisfying results. Following electrochemical oxidation process, other treatment processes can be applied untill discharge standards. But, the authors aimed to catch discharge standards with the application of electrochemical oxidation process. The addition of $1 \mathrm{~g} / \mathrm{L} \mathrm{NaCl}$ results $86 \%$ COD and $90 \%$ colour removal efficiencies. These removal efficiencies are good enogh for Turkish Discharge Standards for evaluated textile industry. Increasing amount of salt did not affect COD and colour removal efficiencies dramatically. On the other hand, increasing salt content reduces voltage of electrochemical stystem. But added salt content create a further environmental problen in future for discharging of treated waste streams. From these reasons 1 $\mathrm{g} / \mathrm{L} \mathrm{NaCl}$ addition choosen as optimum for tested wastewater in this study.

\section{B. Effect of initial $p H$}

For electrochemical oxidation processes, $\mathrm{pH}$ has an important role. The effect of $\mathrm{pH}$ tested between 3-9 at constant density $50 \mathrm{~mA} / \mathrm{cm}^{2}$ and $1 \mathrm{~g} / \mathrm{L} \mathrm{NaCl}$ concentration. In the acidic range, COD and colour removal efficiencies higher than basic range removal efficiencies (Fig. 3). In acidic range, ozone generation capacity of $\mathrm{Sn}-\mathrm{Sb}-\mathrm{Ni}$ anodes are dominant [6,24]. Another imporant oxidizing agent, chlorin gas, is produced at acidic $\mathrm{pH}$ range on anode surface. At this $\mathrm{pH}$ range chlorine gas generates hypochloric acid. On the other hand, COD and colour removal efficiencies may also dominated by hydroxyle radicals, which is generated by ozone at anode surface and hydrogen peroxide at cathode surface under these conditions instantly. But, it is not possible to determine most effective or dominant oxidizing agent for a real wastewater studies.

3,4,5 and $6 \mathrm{pH}$ removal efficiencies were too similar for both COD and colour removal. But, neutral $\mathrm{pH}$ values shown slightly lower removal efficiencies than acidic $\mathrm{pH}$ values $(3 \%)$. These results are also supported by literature [25]. Acidic and basic $\mathrm{pH}$ regions could support the treatment of organics, theoretically. In acidic conditions hydroxyle radical (generated on anode surface) scavengers $\left(\mathrm{HCO}_{3}^{-}\right.$and $\left.\mathrm{CO}_{3}{ }^{-}\right)$can be eleminated and removal of organics can be increased. Alcaline conditions can also support the removal of organics parallel to chlorine gas and hypochlorite ion production [26,27]. Although, acidic $\mathrm{pH}$ values shown slightly better COD and colour (Fig.4 and 5) removal efficiencies, 7,2 natural $\mathrm{pH}$ of samples were chosen as optimum $\mathrm{pH}$ for further experiments to avoid extra operational cost for $\mathrm{pH}$ adjustment.

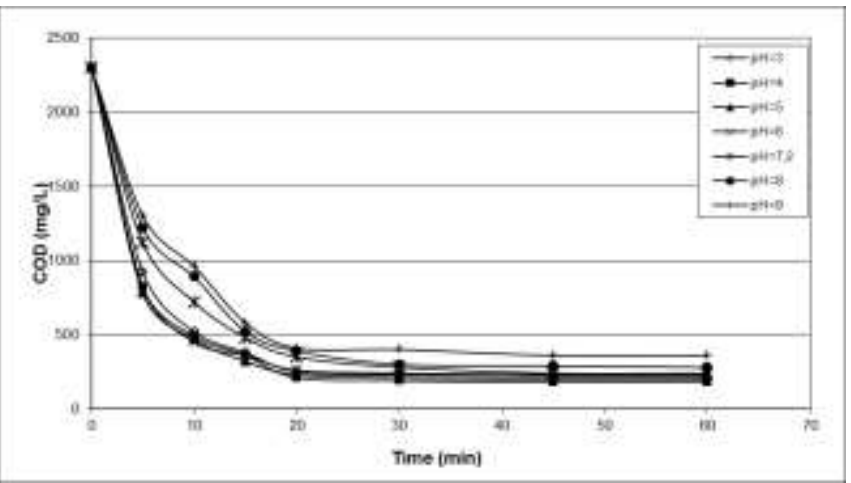

Fig.4 Effect of $\mathrm{pH}$ on COD removal $\left(\mathrm{I}=50 \mathrm{~mA} / \mathrm{cm}^{2}, \mathrm{NaCl}\right.$ add. $\left.=1 \mathrm{~g} / \mathrm{L}\right)$

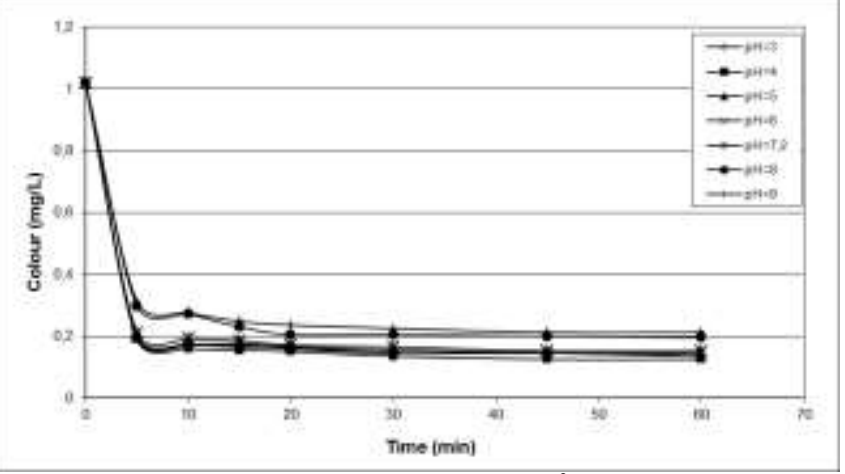

Fig. 5 Effect of $\mathrm{pH}$ on colour removal $\left(\mathrm{I}=50 \mathrm{~mA} / \mathrm{cm}^{2}, \mathrm{NaCl}\right.$ add. $\left.=1 \mathrm{~g} / \mathrm{L}\right)$ 
As it can be seen from both Fig 4 and Fig.5 effect of $\mathrm{pH}$ on the electrochemical treatment of textile effluent cannot be detected. Acidic and neutral $\mathrm{pH}$ values have shown slightly better results than basic conditions. Briefly, effect of $\mathrm{pH}$ on the electrochemical treatment of real textile wastewater is too limited and not so clear in literature. For further studies, the authors will be concentrated on the understanding of effect of $\mathrm{pH}$ on the electrochemical removal of COD and colour from textile effluent.

\section{Effect of Current Density}

Current density is another important parameter for electrochemical processes controlling the reaction rate [27]. To detect the effect of current density on COD and colour removal from tested samples, $10-100 \mathrm{~mA} / \mathrm{cm}^{2}$ was applied $(\mathrm{pH}=7.2$ and $1 \mathrm{~g} / \mathrm{L} \mathrm{NaCL})$. Increasing current densities increased the COD and colour removal effciencies. A possible reason to explain this situation is increasing generation of active oxidizing agent production under high current densities. Fig 6 and 7 shows the effect of current density on COD and colour removal efficiencies.

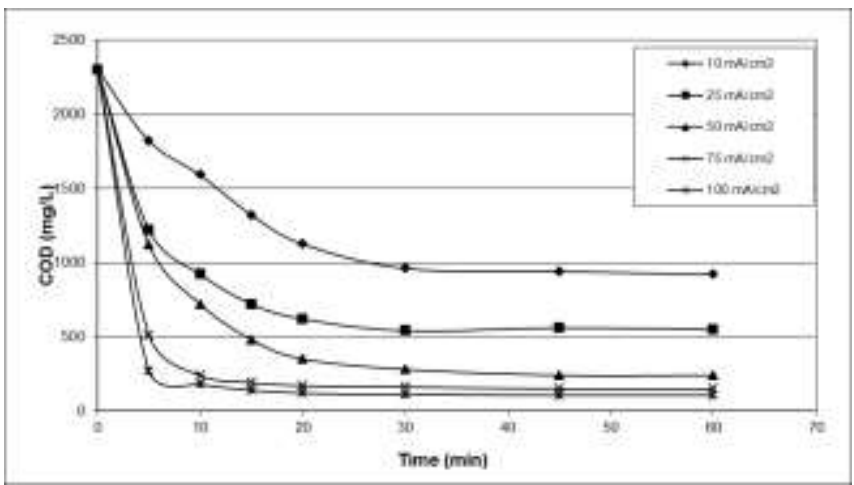

Fig.6 Effect of Current Density on COD removal $(\mathrm{pH}=7.2, \mathrm{NaCl}$ add.=1 $\mathrm{g} / \mathrm{L})$

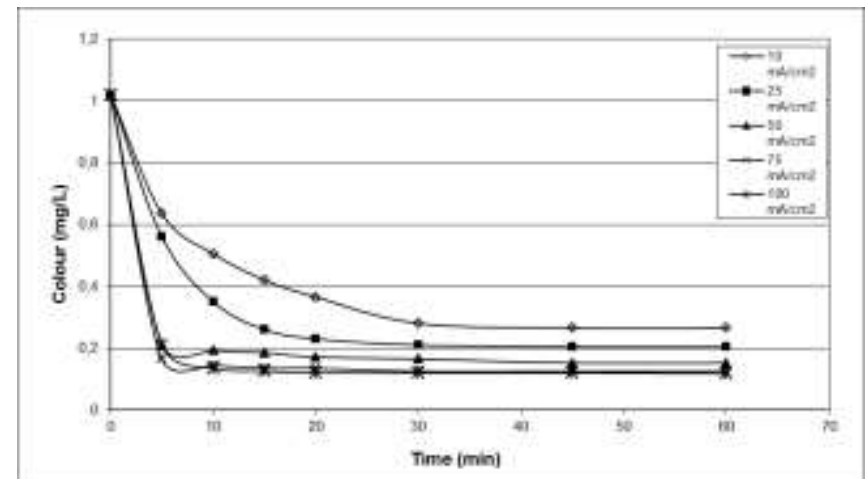

Fig.7 Effect of Current Density on COD removal $(\mathrm{pH}=7.2, \mathrm{NaCl}$ add.=1 $\mathrm{g} / \mathrm{L})$

According to Fig 6 and 7 lower current densities decreases the $\mathrm{COD}$ and colour removal efficiencies. 10 and 25 $\mathrm{mA} / \mathrm{cm}^{2}$ current density values also can not be reached discharge limits on COD. But, 50 and over current densities meet discharge limits on evaluated parameters. Over 50 $\mathrm{mA} / \mathrm{cm}^{2}$ current density values decreases hydraulic retention time value less than 10 mins. But increasing current density means increasing power consumption. To chose correct value for current density power cunsumption values calculated. As shown in Fig 8., increasing current density increses power consumption dramatically. Consequently, according to power consumption calculations $50 \mathrm{~mA} / \mathrm{cm}^{2}$ current density is fit for evaluated wastewater.

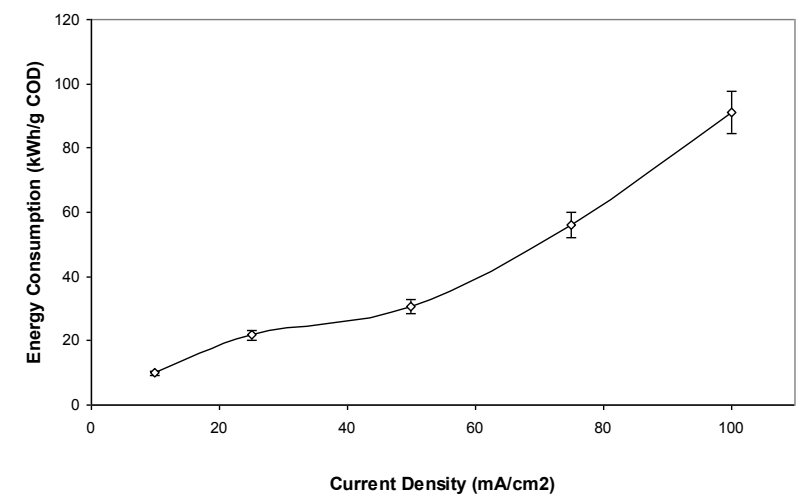

Figure 8. Power consumption values according to applied current density

\section{Iv. Conslusions}

In this study, treatment of real textile wastewater by electrochemical oxidation using new series of $\mathrm{Sn}-\mathrm{Sb}-\mathrm{Ni}$ anodes. Consequently;

(1) COD and colour content of real textile dyeing factory wastewater decreased $90 \%$ and $94 \%$, respectively.

(2) Salt addition positively affected the COD and colur removal efficiencies. Salt addition increased COD and colour removal efficiencies from $60 \%$ to $91 \%$.

(3) All $\mathrm{pH}$ values tested to remove COD and colour content of wastewater samples have not been shown great differences. From this reason, natural $\mathrm{pH}$ of wastewater can be used as optimum $\mathrm{pH}$ value.

(4) Current density is strongly effecting COD and colour removal. But increasing current density values is also increasing power consumption dramaticaly.

\section{Acknowledgement}

The authors acknowledge the Uludağ University, Department of Research Projects for funding this study (Project No. OUAP-M-2012/10).

\section{References}

[1] Yonar, T.; Yonar, G.K.; Kestioglu, K., Azbar, N., 2005. Decolorisation of Textile Effluent Using Homogeneous Photochemical Oxidation Processes. Colour. Technol. 121, 258-264

[2] Yonar, T., 2010. Treatability Studies on Traditional Hand-Printed Textile Industry Wastewaters Using Fenton and Fenton-Like Processes: Plant Design and Cost Analysis. Fresenius Environmental Bulletin, 19, (12), 2758-2768.

[3] Naumczyk, J., Szpyrkowicz, L., Zilio-Grandi, F., 1996. Electrochemical treatment of textile wastewater, Wat Sci Technol 1996, 34 (11) 17-24.

[4] Korbahti, B.K., Tanyolac, A., 2008. Electrochemical treatment of simulated textile wastewater with industrial components and Levafix Blue CA reactive dye: Optimization through response surface methodology. Journal of Hazardous Materials, 151, (2-3), 422-431.

[5] Nordin, N., Amir,S.F.M., Riyanto, Othman,M.R., 2013.Textile Industries Wastewater Treatment by Electrochemical Oxidation 
Proc. of the International Conference on Advances in Bio-Informatics and Environmental Engineering - ICABEE 2016. Copyright (c) Institute of Research Engineers and Doctors. All rights reserved.

ISBN: 978-1-63248-100-9 doi: 10.15224/ 978-1-63248-100-9-24

Technique Using Metal Plate. Int. J. Electrochem. Sci., 8, 11403 11415

[6] Christensen, P.A., Zakaria,K., Christensen, H.C., Yonar,T., 2013. The Effect of $\mathrm{Ni}$ and $\mathrm{Sb}$ Oxide Precursors, and of $\mathrm{Ni}$ Composition, Synthesis Conditions and Operating Parameters on the Activity, Selectivity and Durability of Sb-Doped $\mathrm{SnO} 2$ Anodes Modified with Ni. Journal of the E lectrochemical Society, 160, (8), H405. H413.

[7] Basiriparsa J., Abbasi M. 2012. High efficiency ozone generation via electrochemical oxidation of water using Ti anode coated with Ni- Sb$\mathrm{SnO}_{2}$. Journal of Solid State Electrochemistry, 16, 1011-1018.

[8] Zakaria,K., Christensen,P.A., 2014. The use of Ni/Sb-SnO2-based membrane electrode assembly for electrochemical generatin of ozone and the decolourisation of Reactive Blue 50 dye solution. Electrochimica Acta, 135, 11-18.

[9] Da Silva L.M., Jardim W.F. 2006. Trends and strategies of ozone application in environmental problems. Quimica Nova, 29, (2), 310317.

[10] Da Silva L.M., Franco D.V., Sousa L.G., Gonçalves I.C. 2010. Characterization of an electrochemical reactor for the ozone production in electrolyte free water. Journal of Applied Electrochemistry, 40, 885-864.

[11] Stucki S., Baumann, H.J., Christen H.J. Kötz R. 1987. Performance of a pressurized electrochemical generator. Journal of Applied Electrochemistry, 17, 773-778.

[12] Cui Y., Wang Y., Wang B., Zhou H., Chan K.Y., Li X.Y. 2009. Electrochemical generation of ozone in a membrane electrode assembly cell with convective flow. Journal of Electrochemical Society, 156, (4), E75-E80.

[13] Park S.L., Moon J.D., Lee S.H., Shin S.Y. 2006. Effective ozone generation utilizing a meshed-plate electrode in a dielectric-barrier discharge type ozone generator. Journal of Electrostatics, 64, 275-282.

[14] Barlow P.J. 1994. An introduction to ozone generation. (http://www.lifelineozone.com/research/ozone\%20basics/basic1.pdf).

[15] Da Silva L.M., De Faria L.A., Boodts J.F.C. 2001. Green processes for environmental application. Electrochemical ozone production. Pure and Applied Chemistry ,73, (12), 1871-1884.

[16] Han S.D., Kim J.D., Singh K.C., Chaudry R.S. 2004. Electrochemical generation of ozone using solid polymer electrolyte-State of the art. Indian Journal of Chemistry -Section A, 43, 1599-1614.

[17] Basiriparsa J., Abbasi M. 2012. Application os in situ electrochemically generated ozone for degredation of antraquninone dye Reactive Blue 19. J Appl Electrochem, 42, 435-442

[18] Da Silva L.M. and Santana M.H.P. 2003. Electrochemistry and green chemical processes: Electrochemical ozone production. Quimica Nova, 26, (6), 880-888.

[19] Wang Y.H., Chen Q.Y. 2013. Anodic Materials for Electrocatalytic Ozone Generation, International Journal of Electrochemistry, Volume 2013.

[20] Abbasi M., Soleymani A.R., Basiriparsa J. 2014. Operation simulation of a recycled electrochemical ozone generator using artificial neural network. Chemical Engineering Research and Design, 92, (11), 26182625.

[21] Basiri Parsa, J., Golmirzaei, M, Abbasi, M., 2014. Degradation of azo dye C.I. Acid Red 18 in aqueous solution by ozone-electrolysis process. J. of Industrial and Engineering Chemistry, 20, 689-694.

[22] Pillai, I.M.S , Gupta,A.K., 2016. Anodic oxidation of coke oven wastewater: Multiparameter optimization for simultaneous removal of cyanide, COD and phenol. Journal of Environmental Management, $176,45-53$.

[23] Carliell,C.M., Barclay,S.J., Shaw,C., Wheatley,A.D., Buckley,C.A., 1998. The Effect of Salts Used in Textile Dyeing on Microbial Decolourisation of a Reactive Azo Dye Environmental Technology, $19,(11), 1133-1137$

[24] Wang, Y. H., Cheng, S. A., Chan, K. Y., Li, X. Y. 2005. Electrolytic Generation of Ozone on Antimony- and Nickel-Doped Tin Oxide Electrode. Journal of the Electrochemical Society, 152, (11), D197D200.

[25] Khezrianjoo, S., Revanasiddappa, H.D., 2016. Evaluation of kinetics and energy consumption of the electrochemical oxidation of Acid Red 73 in aqueous media. Toxicological \& Environmental Chemistry, 98, (7), 759-767.
[26] Li,X.M., Wang,M., Jiao, Z.K., Chen,Z.Y., 2001. Study on electrolytic oxidation for landfill leachate treatment. China Water \&Wastewater, 17, (8), 14-17.

[27] Deng,Y., Englehardt, J.D., 2007. Electrochemical oxidation for landfill leachate treatment. Waste Management, 27, 380-388.

About Author (s):

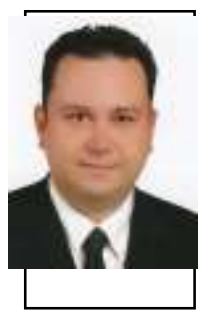

Taner Yonar has a B.Sc. (1996) degree in Environmental Engineering, Uludag University, a M.Sc. (1999) degree in Environmental Sciences, Uludag University. He has completed his $\mathrm{PhD}$ (2005) in Environmental Technology, at Uludag University in 1997-2007. He did his post-doctoral research in UK, at Newcastle University (2011). He is currently working as an Associate Professor at the Environmental Engineering Department of Uludag University.

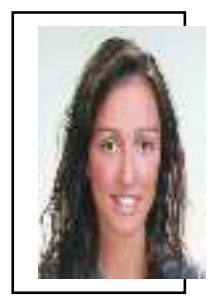

Özge Sivrioğlu has a B.Sc. (2007) degree in Environmental Engineering, Uludag University, a M.Sc. (2010) degree in Environmental Technology, Uludag University. He has completed his $\mathrm{PhD}$ (2005) in Environmental Technology, at Uludag University in 1997-2007 She started her $\mathrm{PhD}$ in 2010 and she is is currently working as a Research Assistant at the Environmental Engineering Department of Uludag University. 